\title{
PREFATORY NOTE TO SECOND EDITION
}

Research for the second edition of this book was supported by the University of Scranton in the form of faculty development funds, annual released time, and a sabbatical leave. For providing me with access to theatrical materials, I owe a great deal to the staff members at various institutions, including the Shakespeare Centre Library, the National Theatre Archive, the Globe Education Centre, the Stratford, Ontario Shakespeare Festival Archive, and the Shakespeare Theatre of Washington, DC. I also appreciate the editorial assistance and prompt answers to questions that I invariably received from my contacts at Manchester University Press.

I offer thanks to general editors Jim Bulman and Carol Rutter for their invitation to take on this project, as well as for their constant encouragement of my efforts and their constructive criticism of my early drafts. Mariangela Tempera, one of my predecessors as a stage historian of Titus Andronicus, was also incredibly generous with her help. And, of course, I could not have completed this project without the love of my family: Cheryl, Rachael, and Casey. Finally, I am monumentally indebted to Alan Dessen, not only for nominating me to continue his work, but also for the tremendous support he has offered to me throughout my career as a Shakespearean. 
Michael D. Friedman and Alan Dessen - 9781526101914 Downloaded from manchesterhive.com at 04/26/2023 09:37:53AM 